\title{
Pengaruh Pemahaman Wajib Pajak dan Manfaat Pajak Restoran Terhadap Kemauan Wajib Pajak Membayar Pajak (Studi Kasus Pada Usaha Restoran di Kabupaten Minahasa dan Kota Tomohon)
}

\author{
Oleh : \\ Pingkan Elni Wowor ${ }^{1}$ \\ Jullie J. Sondakh ${ }^{2}$ \\ Sherly Pinatik ${ }^{3}$
}

\author{
Fakultas Ekonomi Dan Bisnis \\ Universitas Sam Ratulangi Manado \\ Email : ${ }^{1}$ pingkan.wowor@ymail.com
}

\begin{abstract}
Tax is one of the sources of government revenue that can be relied upon, in this case, especially in the financing of local government. But in the collection muidah it would not, because in addition demanded the active role of taxation officers are also required the willingness of the taxpayer itself in paying taxes. Lack of willingness of taxpayers to pay their taxes can not be separated from the lack of knowledge on taxation, as well as the lack of such benefits in the eyes of society. Many still regard as a tax expenditure in vain. this is one of the factors that hinder the taxpayer in carrying out their tax obligations. Purpose of this study was to determine the understanding of taxpayers and tax benefits restaurant on the willingness of taxpayers to pay taxes in Minahasa district and in the town of Tomohon. Methods of analysis used in this study is the method of multiple linear regression analysis.

Testing hypotheses used in this study is the F test and T test $F$ test is to determine the effect of independent variables on the dependent variable simultaneously, whether significant effect or not, and T test to determine the effect of independent variables on the dependent variable partially, whether the effect significant or not.

Based on the results of research conducted shows that in Minahasa, simultaneously understanding of the taxpayer and the tax benefit Restaurant significant effect on the willingness of taxpayers to pay taxes, and partial understanding of the taxpayer does not affect the willingness of taxpayers taxpayer, while the effect on the restaurant tax benefits the willingness of taxpayers taxpayer. In Tomohon, simultaneously understanding of the taxpayer and the tax benefit Restaurant significant effect on the willingness of taxpayers to pay taxes, and partial understanding of the taxpayer and the tax benefits of the restaurant affect the willingness of taxpayers taxpayer. This is evidenced by testing of the data obtained in this study.
\end{abstract}

Keywords: Understanding the taxpayer, Tax benefits, The willingness of taxpayers

\section{PENDAHULUAN}

Pembiayaan pemerintah dalam melaksanakan tugas pemerintah dan pembangunan senantiasa memerlukan sumber penerimaan yang dapat diandalkan. Dalam hal ini termasuk juga untuk pembiayaan pemerintah daerah. Kebutuhan ini semakin dirasakan oleh daerah terutama sejak diberlakukannya otonomi daerah di Indonesia, yaitu mulai tanggal 1 Januari 2001. Dengan adanya otonomi, daerah dipacu untuk dapat berkreasi mencari sumber penerimaan daerah yang dapat mendukung pembiayaan pengeluaran daerah, dari berbagai alternatif sumber penerimaan 
yang mungkin dipungut oleh daerah tersebut. Undang-undang tentang Pemerintahan daerah menetapkan pajak daerah menjadi salah satu sumber penerimaan yang berasal dari dalam daerah dan dapat dikembangkan sesuai dengan kondisi masing-masing daerah.

Dalam meningkatkan Pendapatan Asli Daerah ini, salah satu pajak daerah yang memberikan kontribusi yang cukup besar di kabupaten/kota adalah pajak restoran. Berbicara soal restoran atau fasilitas penyedia makanan dan atau minuman ini, tentulah sangat banyak terdapat di berbagai tempat karena merupakan salah satu kebutuhan pokok manusia yang sangat dibutuhkan setiap hari. Namum sejak reformasi perpajakan tahun 1983, sistem pemungutan pajak di Indonesia mengalami perubahan. Sejak saat itu Indonesia menganut sistem self assessment. Sangat berbeda dari masa sebelumnya, mulai saat itu wajib pajak diberi kepercayaan untuk menghitung pajaknya sendiri. Keberhasilan sistem ini sangat ditentukan oleh kepatuhan sukarela wajib pajak dan pengawasan yang optimal dari aparat pajak. Mereka menghitung, memperhitungkan, menyetor dan melaporkan pajaknya sendiri. Pajak yang disetor wajib pajak tersebut dianggap benar, sampai pemerintah dapat membuktikannya salah.

Tetapi fakta menunjukan sebagian besar wajib pajak masih enggan membayar pajak dengan benar atau, masih banyak wajib pajak potensial yang belum terdaftar sebagai wajib pajak yang aktual. Pemungutan pajak memang bukanlah hal yang mudah, selain dibutuhkan peran aktiv petugas perpajakan dibutuhkan juga kemauan membayar pajak dari wajib pajak itu sendiri. Oleh karena itu dalam pembayaran pajak, dalam hal ini termasuk juga pembayaran pajak restoran, sangatlah dibutuhkan kemauan secara pribadi oleh wajib pajak tersebut dalam melaporkan dan membayar pajaknya.

Menurut peneliti kurangnya pemahaman serta kemauan wajib pajak di kabupaten Minahasa dan kota Tomohon tentang peraturan perpajakan dan manfaatnya dapat mempengaruhi tingkat kemauan bahkan jumlah wajib pajak dalam pembayaran pajak. Wajib pajak yang memahami peraturan perpajakan bahkan memiliki kesadaran mengenai manfaat pajak tersebut secara otomatis akan merespon dengan baik dan melaksanakan tanggung jawabnya tersebut dalam membayar pajak. Berdasarkan latar belakang masalah penelitian diatas, maka dapat dirumuskan masalah, Apakah pemahaman wajib pajak dan manfaat pajak restoran berpengaruh terhadap kemauan wajib pajak membayar pajak di Kabupaten Minahasa dan di Kota Tomohon secara simultan dan parsial.

Tujuan dalam penelitian ini adalah untuk mengetahui pengaruh pemahaman wajib pajak dan manfaat pajak restoran terhadap kemauan wajib pajak membayar pajak di Kabupaten Minahasa dan di Kota Tomohon ecara simultan dan parsial.

\section{TINJAUAN PUSTAKA}

Menurut Libby, Libby, Short (2008:4), Akuntansi merupakan sistem yang mengumpulkan dan memproses (menganalisis, menghitung, dan mencatatat) informasi keuangan mengenai sebuah organisasi dan melaporkan informasi tersebut kepada pengambil keputusan.

Menurut Siahaan (2010:7), Secara umum pajak adalah pungutan dari masyarakat oleh Negara (pemerintah) berdasarkan undang-undang yang bersifat dapat dipaksakan dan terutang oleh yang wajib membayarnya dengan tidak mendapat prestasi kembali (kontra prestasi/balas jasa) secara langsung, yang hasilnya digunakan untuk membiayai pengeluaran Negara dalam penyelenggaraan pemerintahaan dan pembangunan.

Siahaan (2010:9), Pajak Daerah adalah iuran wajib yang dilakukan oleh daerah kepada orang pribadi atau badan tanpa imbalan langsung yang seimbang, yang dapat dipaksakan berdasarkan peraturan perundang-undangan yang berlaku, yang digunakan untuk membiayai penyelenggaraan pemerintah daerah dan pembangunan daerah. 
Siahaan (2010:44), Undang-undang Nomor 34 tahun 2000 memberikan peluang kepada daerah kabupaten/kota untuk memungut jenis pajak daerah lain yang dipandang memenuhi syarat, selain ketujuh jenis pajak kabupaten/kota yang telah ditetapkan.

Menurut Widyaningsih (2013:217), Pajak Restoran adalah pajak atas pelayanan yang disediakan oleh restoran. Restoran adalah fasilitas penyedia makanan dan/ atau miniman dengan dipungut bayaran, yang mencakup juga rumah makan, kafetaria, kantin, warung, bar, dan sejenisnya termasuk jasa boga/katering.

Menurut Kamus Besar Bahasa Indonesia, faktor adalah hal (keadaan atau peristiwa) yang ikut menyebabkan terjadinya sesuatu. Berdasarkan pengertian tersebut, keadaan atau peristiwa yang dapat melatarbelakangi wajib pajak restoran dalam membayar pajaknya adalah :

Pemahaman tentang perpajakan sangat penting karena dapat membantu wajib pajak dalam memenuhi aturan perpajakan. Menurut Ramadiansyah (2014:3), pemahaman merupakan kemampuan untuk menangkap makna dan arti dari bahan yang dipelajari. Dalam hal ini tentang peraturan pajak restoran.

Menurut Kamus Besar Bahasa Indonesia, manfaat adalah guna atau faedah. Jadi dapat disimpulkan, manfaat yang diasakan wajib pajak adalah guna atau faedah yang diterima atau dirasakan wajib pajak atas pembayaran pajaknya, dalam hal ini pembayaran pajak restoran.

Menurut Kamus Bahasa Indonesia, kemauan adalah apa yang dimaui, keinginan atau kehendak. Berdasarkan pengertian ini dapat disimpulkan, kemauan wajib pajak adalah suatu kondisi dimana wajib pajak mau, ingin dan berkehendak untuk melaksanakan ketentuan perpajakan dengan benar. Dalam hal ini ketentuan pajak restoran.

\section{METODE PENELITIAN}

\subsection{Data}

Jenis penelitian yang digunakan dalam penelitian ini adalah Asosiatif. Penelitian ini dilakukan di Kabupaten Minahasa dan Kota Tomohon dengan objek penelitian Pengusaha Restoran di Kabupaten Minahasa dan Pengusaha Restoran di Kota Tomohon. Periode waktu penelitian dilakukan selama bulan Maret 2015. Adapun langkah-langkah yang telah dilakukan dan nantinya akan dilakukan dalam pelaksanaan penelitian ini adalah sebagai berikut :

1. Observasi Tempat Penelitian

2. Mengajukan Permohonan Penelitian

3. Pengumpulan Data

4. Analisa Data Penelitian

5. Analisa Penerapan

6. Kesimpulan dan Saran

Populasi dalam penelitian ini adalah wajib pajak restoran yang yang terdaftar di Dinas Kebudayaan dan Pariwisata Kabupaten Minahasa yaitu 77 wajib pajak dan wajib pajak restoran yang yang terdaftar di Dinas Kebudayaan dan Pariwisata Kota Tomohon, yaitu 101 wajib pajak yang masih aktif menjalankan usahanya sampai pada akhir tahun 2014. Sampel untuk Kabupaten Minahasa adalah 43 wajib pajak restoran dan sampel untuk Kota Tomohon adalah 50 wajib pajak restoran.

Menurut Priadana (2009:3), jenis data terbagi menjadi :

1. Kuantitatif, menekankan pada pengujan teori-teori melalui pengukuran variabelvariabel penelitian dengan angka dan melalui analisis data dengan prosedur statistik.

2. Kualitatif, merupakan paradigma penelitian yang menekankan pada pemahaman mengenai masalah-masalah dalam kehidupan sosial berdasarkan kondisi realitas atau natural setting yang holistik, komplek dan rinci. 
Menurut Soeratno dan Arsyad (2008:70), sumber data terbagi menjadi :

1. Data Primer

Data yang dikumpulkan dan diolah sendiri oleh organisasi yang menerbitkan atau menggunakannya.

2. Data Sekunder

\subsection{Definisi Variabel}

Data yang diterbitkan atau digunakan oleh organisasi yang bukan pengelolahnya.

Menurut Siahaan (2013:2) Variabel merupakan konsep yang nilainya bervariasi atau berubah-ubah. Ada beberapa macam variabel sebagai berikut :

a. Variabel Dependen (variabel terkait) adalah variabel yang nilainya dipengaruhi oleh variabel lain.

b. Variabel Independen (variabel bebas) adalah variabel yang mempengaruhi variabel lain.

c. Variabel Kontrol adalah variabel yang dikendalikan, atau nilainya dibuat tetap, hal ini agar tidak dipengaruhi oleh variabel lain.

d. Variabel Moderator adalah variabel yang mempengaruhi hubungan antara variabel independen dengan variabel dependen.

Dalam penelitian ini menggunakan variabel dependen dan variabel independen.

\subsection{Metode Analisis Data}

Metode analisis data yang digunakan dalam penelitian ini adalah Uji Validitas dan Reliabilitas, Uji Asumsi Klasik, Analisis Regresi Linier Berganda, Uji F, dan Uji t.

\section{HASIL PENELITIAN DAN PEMBAHASAN}

\subsection{Hasil Penelitian}

Minahasa berasal dari kata Minaesa yang berarti persatuan, yang mana zaman dahulu Minahasa dikenal dengan nama Malesung. Menurut penyelidikan dari Wilken dan Graafland bahwa pemukiman nenek moyang orang Minahasa dahulunya di sekitar pegunungan Wulur Mahatus, kemudian berkembang dan berpindah ke Mieutakan (daerah sekitar Tompaso baru saat ini).

Nama Tomohon berasal dari kata Tou Mu'ung, yang berarti orang Mu'ung.Tidak begitu jelas mengapa dinamakan orang Mu'ung.Tapi dengan adanya sebuah mata air besar bernama Mu'ung yang kini terdapat di kelurahan Matani II, diduga inilah asal mula penamaan tempat ini.Tou Mu'ung yang karena gubahan lidah berubah menjadi Tomohon.Orang Tomohon sering juga disebut orang Toumbulu, yaitu penduduk pengguna bahasa sub etis Toumbulu.Toumbulu artinya orang wuluh, atau orang gunung.Hingga kini pengguna bahasa Tombulu terdapad di kurang lebih 120 negeri baik yang berstatus desa maupun kelurahan.

\section{Uji Validitas dan Reliabilitas}

Berdasarkan hasil uji yang dilakukan di kabupaten Minahasa dan kota Tomohon, nilai signifikan untuk setiap pernyataan adalah < alpha yaitu 0,05 maka dapat disimpulkan bahwa setiap pernyataan pada variabel Pemahaman Wajib Pajak (X1), Manfaat Pajak Restoran (X2) dan Kemauan Membayar Pajak (Y) dikatakan valid. Nilai alpha cronbach untuk setiap pernyataan > 0,6 maka dapat disimpulkan bahwa setiap pernyataan dikatakan reliabel.

\section{Uji Asumsi Klasik}




\section{Gambar 4.1 Hasil Uji Normalitas Kab. Minahasa}

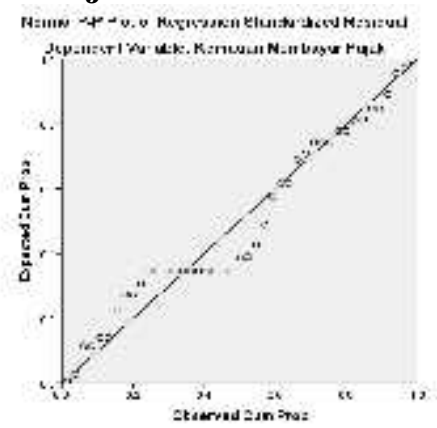

Berdasarkan gambar hasil uji normalitas diatas dapat dilihat bahwa data menyebar disekitar garis diagonal dan mengikuti arah garis diagonal menunjukan pola distribusi normal. Dengan demikian dapat disimpulkan model regresi di Kabupaten Minahasa memenuhi asumsi normalitas.

\section{Gambar 4.2 Hasil Uji Normalitas Kota Tomohon}

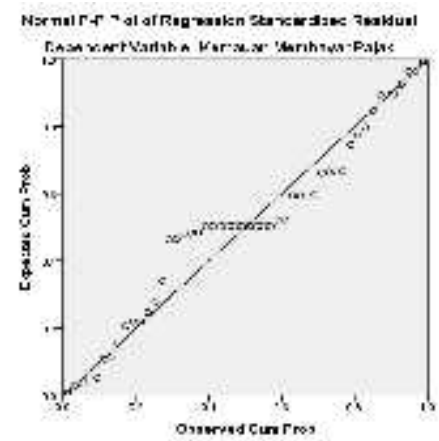

Berdasarkan gambar hasil uji normalitas diatas dapat dilihat bahwa data menyebar disekitar garis diagonal dan mengikuti arah garis diagonal menunjukan pola distribusi normal. Dengan demikian dapat disimpulkan model regresi di Kota Tomohon memenuhi asumsi normalitas.

Tabel 4.6 Hasil Uji Multikolinieritas Kab. Minahasa

\begin{tabular}{lll}
\hline \multirow{2}{*}{ Model } & \multicolumn{2}{l}{ Collinearity Statistics } \\
& Tolerance & VIF \\
\hline (Constant) & \multicolumn{3}{l}{} \\
\hline Pemahaman Wajib Pajak & .262 & 3.812 \\
\hline Manfaat Pajak Restoran & .262 & 3.812 \\
\hline Hasil Pengolahan Data, 2015 &
\end{tabular}

Dari hasil olahan data, diperoleh nilai tolerance $>0,1$ yaitu 0,262 dan nilai VIF $<10$ yaitu 3,812 untuk variabel $\mathrm{X}_{1}, \mathrm{X}_{2}$ dalam penelitian ini. Dengan demikian dapat disimpulkan bahwa tidak ada multikolinieritas antara variabel independen pada model regresi ini. 
Tabel 4.7 Hasil Uji Multikolinieritas di Kota Tomohon

\begin{tabular}{lcc}
\hline Model & \multicolumn{2}{c}{$\begin{array}{c}\text { Collinearity } \\
\text { Tolatistics }\end{array}$} \\
& \multicolumn{2}{c}{} \\
\hline (Constant) & VIF \\
\hline Pemahaman Wajib Pajak & .879 & 1.138 \\
\hline Manfaat Pajak Restoran & .879 & 1.138 \\
\hline Hasil Pengolahan Data, 2015 &
\end{tabular}

Dari hasil olahan data, diperoleh nilai tolerance $>0,1$ yaitu 0,879 dan nilai VIF $<10$ yaitu 1,138 untuk variabel $\mathrm{X}_{1}, \mathrm{X}_{2}$ dalam penelitian ini. Dengan demikian dapat disimpulkan bahwa tidak ada multikolinieritas antara variabel independen pada model regresi ini.

Gambar 4.3 Hasil Uji Heteroskedastisitas Kab. Minahasa

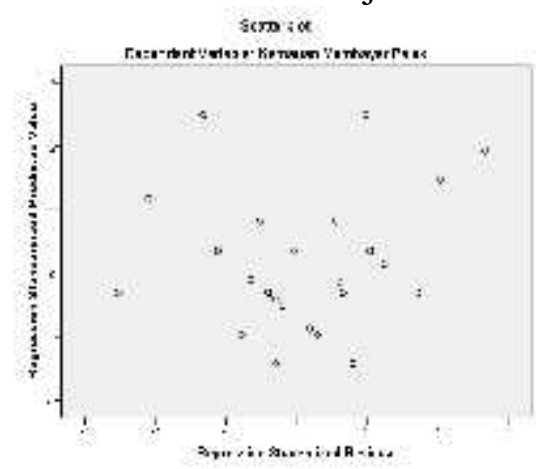

Hasil Pengolahan Data, 2015

Dari hasil Uji Heteroskedastisitas ini, dapat dilihat bahwa titik-titik menyebar dengan pola yang tidak jelas di atas dan di bawah angka 0 pada sumbu Y. Dengan demikian dapat disimpulkan pada model regresi ini tidak terjadi masalah heteroskedastisitas.

Gambar 4.4 Hasil Uji Heteroskedastisitas Kota Tomohon

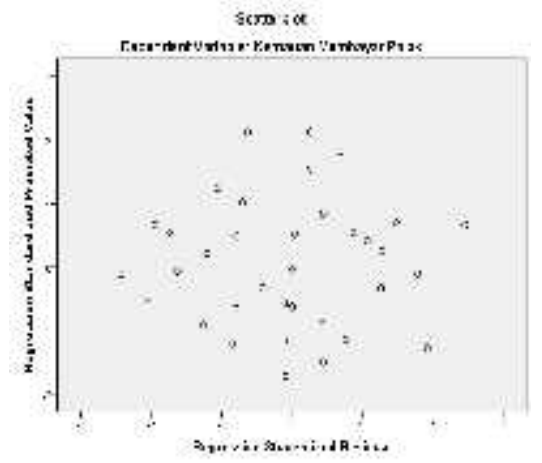

Hasil Pengolahan Data, 2015

Dari hasil Uji Heteroskedastisitas ini, dapat dilihat bahwa titik-titik menyebar dengan pola yang tidak jelas di atas dan di bawah angka 0 pada sumbu Y. Dengan demikian dapat disimpulkan pada model regresi ini tidak terjadi masalah heteroskedastisitas. 
Tabel 4.8 Hasil Uji Autokorelasi Kab. Minahasa

Durbin Watson

1.999

Hasil Pengolahan Data, 2015

Berdasarkan hasil pada kolom Durbin-Waston tersebut menunjukan nilai 1,999. Dengan demikian dapat disimpulkan bahwa tidak terjadi Autokorelasi dalam persamaan regresi dalam penelitian ini.

Tabel 4.9 Hasil Uji Autokorelasi Kota Tomohon

Durbin Watson

1.760

Hasil Pengolahan Data, 2015

Berdasarkan hasil pada kolom Durbin-Waston tersebut menunjukan nilai 1,760. Dengan demikian dapat disimpulkan bahwa tidak terjadi Autokorelasi dalam persamaan regresi dalam penelitian ini.

Analisis Regresi Linier Berganda

Tabel 4.10 Hasil Analisis Regresi Linier Berganda di Kab. Minahasa

\begin{tabular}{|c|c|c|}
\hline \multirow[t]{2}{*}{ Model } & \multicolumn{2}{|c|}{$\begin{array}{l}\text { Unstandardized } \\
\text { Coefficients }\end{array}$} \\
\hline & B & Std. Error \\
\hline 1 (Constant) & 9.289 & 1.726 \\
\hline Pemahaman Wajib Pajak & -.100 & .145 \\
\hline Manfaat Pajak Restoran & .654 & .163 \\
\hline
\end{tabular}

Hasil Pengolahan Data, 2015

Persamaan regresi $\mathbf{Y}=\mathbf{9 , 2 8 9}-\mathbf{0 , 1 0 0 X} X_{1}+\mathbf{0 , 5 6 4 X}$ menggambarkan bahwa variabel bebas (independen) Pemahaman Wajib Pajak $\left(\mathrm{X}_{1}\right)$ dan Manfaat Pajak Restoran $\left(\mathrm{X}_{2}\right)$ dalam model regresi tersebut dapat dinyatakan jika satu variabel independen berubah sebesar 1 (satu) dan lainnya konstan, maka perubahan variabel terikat (dependen) Kemauan Membayar Pajak (Y) adalah sebesar nilai koefisien $(b)$ dari nilai variabel independen tersebut.

Konstanta $(\alpha)$ sebesar 9,289 memberikan pengertian bahwa jika Pemahaman Wajib Pajak $\left(\mathrm{X}_{1}\right)$ dan Manfaat Pajak Restoran $\left(\mathrm{X}_{2}\right)$ secara serempak atau bersama-sama tidak mengalami perubahan atau sama dengan nol(0) maka besarnya Keputusan Pembelian (Y) sebesar 9,289 satuan.

Jika nilai $b_{1}$ yang merupakan koefisien regresi dari Pemahaman Wajib Pajak $\left(\mathrm{X}_{1}\right)$ sebesar -0,100 yang artinya mempunyai pengaruh negatif terhadap variabel dependen (Y) mempunyai arti bahwa jika variabel Pemahaman Wajib Pajak $\left(\mathrm{X}_{1}\right)$ bertambah 1 satuan, maka Kemauan 
Membayar Pajak (Y) juga akan mengalami penuruanan sebesar 0,100 satuan dengan asumsi variabel lain tetap atau konstan.

Jika nilai $b_{2}$ yang merupakan koefisien regresi dari Manfaat Pajak Restoran $\left(\mathrm{X}_{2}\right)$ sebesar 0.564 yang artinya mempunyai pengaruh positif terhadap variabel dependen (Y) mempunyai arti bahwa jika variabel Manfaat Pajak Restoran $\left(\mathrm{X}_{2}\right)$ bertambah 1 satuan, maka Kemauan Membayar Pajak (Y) akan mengalami kenaikkan sebesar 0.564 satuan dengan asumsi variabel lain tetap atau konstan.

Tabel 4.11 Hasil Analisis Regresi Linier Berganda di Kota Tomohon

\begin{tabular}{|c|c|c|}
\hline \multirow[t]{2}{*}{ Model } & \multicolumn{2}{|c|}{$\begin{array}{l}\text { Unstandardized } \\
\text { Coefficients }\end{array}$} \\
\hline & B & $\begin{array}{l}\text { Std. } \\
\text { Error }\end{array}$ \\
\hline 1 (Constant) & 1.112 & 2.004 \\
\hline Pemahaman Wajib Pajak & .442 & .084 \\
\hline Manfaat Pajak Restoran & .502 & .082 \\
\hline
\end{tabular}

Hasil Pengolahan Data, 2015

Persamaan regresi $Y=\mathbf{1 , 1 1 2}+\mathbf{0 , 4 4 2} \mathrm{X}_{\mathbf{1}}+\mathbf{0 , 5 0 2 X _ { 2 }}$ menggambarkan bahwa variabel bebas (independen) Pemahaman Wajib Pajak $\left(\mathrm{X}_{1}\right)$ dan Manfaat Pajak Restoran $\left(\mathrm{X}_{2}\right)$ dalam model regresi tersebut dapat dinyatakan jika satu variabel independen berubah sebesar 1 (satu) dan lainnya konstan, maka perubahan variabel terikat (dependen) Kemauan Membayar Pajak (Y) adalah sebesar nilai koefisien $(b)$ dari nilai variabel independen tersebut.

Konstanta $(\alpha)$ sebesar 1,112 memberikan pengertian bahwa jika Pemahaman Wajib Pajak $\left(\mathrm{X}_{1}\right)$ dan Manfaat Pajak Restoran $\left(\mathrm{X}_{2}\right)$ secara serempak atau bersama-sama tidak mengalami perubahan atau sama dengan nol(0) maka besarnya Keputusan Pembelian (Y) sebesar 1,112 satuan.

Jika nilai $b_{1}$ yang merupakan koefisien regresi dari Pemahaman Wajib Pajak $\left(\mathrm{X}_{1}\right)$ sebesar 0,442 yang artinya mempunyai pengaruh positif terhadap variabel dependen (Y) mempunyai arti bahwa jika variabel Pemahaman Wajib Pajak $\left(\mathrm{X}_{1}\right)$ bertambah 1 satuan, maka Kemauan Membayar Pajak (Y) juga akan mengalami kenaikan sebesar 0,442 satuan dengan asumsi variabel lain tetap atau konstan.

Jika nilai $b_{2}$ yang merupakan koefisien regresi dari Manfaat Pajak Restoran $\left(\mathrm{X}_{2}\right)$ sebesar 0.502 yang artinya mempunyai pengaruh positif terhadap variabel dependen (Y) mempunyai arti bahwa jika variabel Manfaat Pajak Restoran $\left(\mathrm{X}_{2}\right)$ bertambah 1 satuan, maka Kemauan Membayar Pajak (Y) akan mengalami kenaikkan sebesar 0.502 satuan dengan asumsi variabel lain tetap atau konstan.

\section{Uji F}

Tabel 4.14 Hasil Uji F Kabupaten Minahasa

\begin{tabular}{|l|l|}
\hline $\mathrm{F}$ & Sig. \\
\hline 22.534 & $.000^{\mathrm{b}}$ \\
& \\
\hline
\end{tabular}

Hasil Pengolahan Data, 2015 
Dari hasil Uji F menunjukan bahwa nilai signifikan adalah 0,000 berarti lebih kecil $(<)$ dari 0,05 maka $\mathrm{H}_{0}$ ditolak atau $\mathrm{H}_{\mathrm{a}}$ diterima. Kesimpulannya yaitu, Pemahaman Wajib Pajak $\left(\mathrm{X}_{1}\right)$ dan Manfaat Pajak Restoran $\left(\mathrm{X}_{2}\right)$ secara bersama-sama berpengaruh signifikan terhadap Kemauan Wajib Pajak Membayar Pajak (Y).

Tabel 4.15 Hasil Uji F Kota Tomohon

\begin{tabular}{|l|l|}
\hline $\mathrm{F}$ & Sig. \\
\hline 50.145 & $.000^{\mathrm{b}}$ \\
& \\
\hline
\end{tabular}

Hasil Pengolahan Data, 2015

Dari hasil Uji F menunjukan bahwa nilai signifikan adalah 0,000 berarti lebih kecil $(<)$ dari 0,05 maka $\mathrm{H}_{0}$ ditolak atau $\mathrm{H}_{\mathrm{a}}$ diterima. Kesimpulannya yaitu, Pemahaman Wajib Pajak $\left(\mathrm{X}_{1}\right)$ dan Manfaat Pajak Restoran $\left(\mathrm{X}_{2}\right)$ secara bersama-sama berpengaruh signifikan terhadap Kemauan Wajib Pajak Membayar Pajak (Y).

Uji t

Tabel 4.16 Hasil Uji t di Kabupaten Minahasa

\begin{tabular}{lll}
\hline Model & T & Sig \\
\hline (Constant) & 5.328 & .000 \\
\hline Pemahaman Wajib Pajak & -689 & .495 \\
\hline Manfaat Pajak Restoran & 4.013 & .000 \\
\hline Hasil Pengolahan Data, 2015 &
\end{tabular}

Dari hasil Uji t dapat diketahui bahwa Probabilitas (signifikansi) $\mathrm{X}_{1}$ sebesar 0,495 lebih besar (>) dari 0,05 maka $\mathrm{H}_{0}$ diterima atau $\mathrm{H}_{\mathrm{a}}$ ditolak. Kesimpulannya yaitu Pemahaman Wajib Pajak $\left(\mathrm{X}_{1}\right)$ tidak berpengaruh terhadap Kemauan Wajib Pajak Membayar Pajak (Y).

Sedangkan untuk Probabilitas (signifikansi) $\mathrm{X}_{2}$ sebesar 0,000 lebih kecil $(<)$ dari 0,05 maka $\mathrm{H}_{\mathrm{a}}$ diterima atau $\mathrm{H}_{0}$ ditolak. Kesimpulannya yaitu Manfaat Pajak Restoran $\left(\mathrm{X}_{2}\right)$ berpengaruh terhadap Kemauan Wajib Pajak Membayar Pajak (Y).

Tabel 4.17 Hasil Uji t di Kota Tomohon

\begin{tabular}{lll}
\hline Model & $\mathrm{T}$ & $\mathrm{Sig}$ \\
\hline (Constant) & .555 & .582 \\
\hline Pemahaman Wajib Pajak & 5.294 & .000 \\
\hline Manfaat Pajak Restoran & 6.123 & .000 \\
\hline Hasil Pengolahan
\end{tabular}

Hasil Pengolahan Data, 2015

Dari hasil Uji t dapat diketahui bahwa Probabilitas (signifikansi) $\mathrm{X}_{1}$ sebesar 0,000 lebih kecil $(<)$ dari 0,05 maka $\mathrm{H}_{\mathrm{a}}$ diterima atau $\mathrm{H}_{0}$ ditolak. Kesimpulannya yaitu Pemahaman Wajib Pajak $\left(\mathrm{X}_{1}\right)$ berpengaruh signifikan terhadap Kemauan Wajib Pajak Membayar Pajak (Y).

Sedangkan untuk Probabilitas (signifikansi) $\mathrm{X}_{2}$ sebesar 0,000 lebih kecil $(<)$ dari 0,05 maka $\mathrm{H}_{\mathrm{a}}$ diterima atau $\mathrm{H}_{0}$ ditolak. Kesimpulannya yaitu Manfaat Pajak Restoran $\left(\mathrm{X}_{2}\right)$ berpengaruh signifikan terhadap Kemauan Wajib Pajak Membayar Pajak (Y). 


\subsection{Pembahasan}

Pengaruh Pemahaman Wajib Pajak Terhadap Kemauan Wajib Pajak Membayar Pajak di Kabupaten Minahasa dan Kota Tomohon.

Pemahaman wajib pajak adalah keadaan dimana wajib pajak mampu untuk menangkap makna dan arti dari bahan yang dipelajari dalam hal ini peraturan perpajakan.

Dengan adanya pemahaman wajib pajak yang benar dapat membuat wajib pajak tersebut mengerti tentang peraturan perpajakan, dalam hal ini pajak restoran. Sehingga hal tersebut secara tidak langsung dapat mendorong kemauan wajib pajak restoran membayar pajak. Di Kabupaten Minahasa, hasil penelitian menunjukkan bahwa pemahaman wajib pajak restoran tidak berpengaruh terhadap kemauan wajib pajak membayar pajak. Arinya bahwa setiap meningkatnya pemahaman wajib pajak maka kemauan wajib pajak membayar pajak akan meningkat namun tidak signifikan.

Di Kota Tomohon, hasil penelitian menunjukkan bahwa pemahaman wajib pajak restoran berpengaruh terhadap kemauan wajib pajak membayar pajak. Arinya bahwa pemahaman wajib pajak restoran tentang peraturan perpajakan semakin baik atau mengalami peningkatan yang berdampak pada peningkatan kemauan wajib pajak membayar pajak, peningkatan tersebut signifikan. Pemahaman wajib pajak restoran tentang peraturan perpajakan ini mempengaruhi naik turunnya kemauan wajib pajak membayar pajak.

Pada kedua objek penelitian ini menunjukan hasil penelitian untuk pengaruh pemahaman wajib pajak terhadap kemauan wajib pajak membayar pajak yang berbeda. Karena di Kabupaten Minahasa pemahaman wajib pajak restoran tentang peraturan perpajakan belum benar atau belum optimal sehingga pemahaman wajib pajak tidak mempengaruhi naik turunnya kemauan wajib pajak restoran membayar pajak. Sedangkan di Kota Tomohon pemahaman wajib pajak restoran tentang peraturan perpajakan semakin baik sehingga pemahaman wajib pajak mempengaruhi naik turunnya kemauan wajib pajak restoran membayar pajak.

\section{Pengaruh Pemahaman Wajib Pajak Terhadap Kemauan Wajib Pajak Membayara Pajak} Di Kabupaten Minahasa Dan Di Kota Tomohon.

Manfaat yang diasakan wajib pajak adalah guna atau faedah yang diterima atau dirasakan wajib pajak atas pembayaran pajaknya, dalam hal ini pembayaran pajak restoran.

Dengan adanya manfaat yang dirasakan wajib pajak, dapat mendorong kemauan wajib pajak restoran tersebut membayar pajak. Di Kabupaten Minahasa dan di Kota Tomohon, menunjukkan hasil penelitian yang sama, yaitu bahwa manfaaat pajak restoran berpengaruh terhadap kemauan wajib pajak restoran membayar pajak. Arinya bahwa manfaat pajak restoran semakin dirasakan atau mengalami peningkatan yang berdampak pada peningkatan kemauan wajib pajak restoran membayar pajak, peningkatan tersebut signifikan. Manfaat pajak restoran ini mempengaruhi naik turunnya kemauan wajib pajak restoran membayar pajak.

Pengaruh Pemahaman Wajib Pajak dan Manfaat Pajak Restoran Terhadap Kemauan Wajib Pajak Membayar Pajak di Kabupaten Minahasa dan di Kota Tomohon.

Di Kabupaten Minahasa dan di Kota Tomohon menunjukkan hasil penelitian yang sama, yaitu bahwa pemahaman wajib pajak dan manfaaat pajak restoran secara bersama-sama berpengaruh terhadap kemauan wajib pajak membayar pajak. Arinya bahwa pemahaman wajib pajak restoran semakin baik dan manfaat pajak restoran semakin dirasakan akan mengalami peningkatan yang berdampak pada peningkatan kemauan wajib pajak restoran membayar pajak, peningkatan tersebut signifikan. Pemahaman wajib pajak dan manfaat pajak restoran ini mempengaruhi naik turunnya kemauan wajib pajak membayar pajak. 


\section{KESIMPULAN}

Di Kabupaten Minahasa secara simultan, pemahaman wajib pajak dan manfaat pajak restoran berpengaruh signifikan terhadap kemauan wajib pajak membayar pajak. Di Kota Tomohon secara simultan, pemahaman wajib pajak dan manfaat pajak restoran berpengaruh signifikan terhadap kemauan wajib pajak membayar pajak. Di Kabupaten Minahasa secara parsial, pemahaman wajib pajak restoran tidak berpengaruh signifikan terhadap kemauan wajib pajak tersebut membayar pajak. Di Kota Tomohon secara parsial, pemahaman wajib pajak restoran berpengaruh signifikan terhadap kemauan wajib pajak tersebut membayar pajak. Di Kabupaten Minahasa secara parsial, manfaat pajak restoran berpengaruh signifikan terhadap kemauan wajib pajak restoran membayar pajak. Di Kota Tomohon secara parsial, manfaat pajak restoran berpengaruh signifikan terhadap kemauan wajib pajak restoran membayar pajak.

Adapun saran yang dapat penulis berikan yaitu, di Kabupaten Minahasa mengingat Pemahaman Wajib Pajak Restoran tentang peraturan pajak restoran secara parsial tidak berpengaruh signifikan terhadap Kemauan Wajib Pajak Membayar Pajak. Maka pemerintah atau petugas pelayanan dan penyuluhan pajak sebaiknya melakukan sosialisasi dan bimbingan secara berkala yang lebih lagi kepada masyarakat. Di Kota Tomohon, mengingat Pemahaman Wajib Pajak serta Manfaat Pajak Restoran yang secara parsial memiliki pengaruh positif yang signifikan serta memberikan kontribusi yang cukup besar terhadap Kemauan Wajib Pajak Membayar Pajak. Maka pemerintah dan petugas pelayanan dan penyuluhan pajak sebaiknya memperhatikan kedua faktor ini.

Dalam penelitian ini pun yang diteliti hanya terbatas pada pengaruh Pemahaman Wajib Pajak dan Manfaat Pajak Restoran Terhadap Kemauan Wajib Pajak Membayar Pajak. Sedangkan faktor-faktor lain yang juga berpengaruh terhadap Kemauan Wajib Pajak Membayar Pajak yang belum diungkap berapa besar pengaruhnya, semoga pada penelitian selanjutnya dapat membahas faktor-faktor lain yang belum diteliti dalam penelitian ini.

\section{DAFTAR PUSTAKA}

Andi Muhamad, Puspa Dwi Fitri, Herawati. (2013). Faktor-Faktor Yang Mempengaruhi Kemauan Membayar Pajak Wajib Pajak Badan Di Kota Padang. Skripsi. E-Jurnal Universitas Bung Hatta.

Fitriandi Primandita, Aryanto Yuda, Priyono Agus Puji. (2010). Kompilasi Undang-Undang Perpajakan Terlengkap 2010. Salemba Empat. Jakarta

Ilyas Wirawan B, Burton Richard. (2013). Hukum Pajak: Teori, Analisis, Dan Perkembangannya. Edisi 6. Salemba Empat. Jakarta.

Libby Robert, Libby Patricia A, Short Daniel G. (2008). Akuntansi Keuangan. Andi. Yogyakarta.

Lubis Irwansyah, Djuanda Gustin, Lubis Ardiansyah. (2010). Review Pajak Orang Pribadi Dan Orang Asing. Salemba Empat. Jakarta.

Mardiasmo. (2011). Perpajakan Edisi Revisi. Andi. Yogyakarta.

Priadana H.Moh.Sidik, Muis Saludin. (2009). Metode Penelitian Ekonomi dan Bisnis. Graha Ilmu. Yogyakarta.

Priyatno Duwi. (2013). Analisi Korelasi, Regresi, Dan Multivariate Dengan SPSS. Gava Media. Yogyakarta.

Ramadiansyah Dimas, Sudjana Nengah, Dwiantmanto. (2014). Analisis Faktor-Faktor Yang Mempengaruhi Wajib Pajak Orang Pribadi Dalam Memenuhi Kewajiban Membayar Pajak. Skripsi. Jurnal e-Perpajakan, Nomor 1 volume 1 Tahun 2014.

Resmi Siti. (2009). Perpajakan: Teori Dan Kasus. Edisi 5. Salemba Empat. Jakarta. 
Siahaan Marihot Pahala. (2010). Pajak Daerah Dan Retribusi Daerah. Cetakan kedua, Rajawali Pers. Jakarta.

Soemarso. (2008). Akuntansi Suatu Pengantar. Salemba Empat. Jakarta.

Soeratno, Arsyad Lincolin. (2008). Motodologi Penelitian Untuk Ekonomi dan Bisnis. Cetakan ke lima, Unit Penerbit dan Percetakan Sekolah Tinggi Ilmu Manajeman YKPN. Yogyakarta.

Sugiyono. (2010). Metode Penelitian Bisnis. Alfabeta. Bandung.

Waluyo. (2009). Akuntansi Pajak. Edisi 2. Salemba Empat. Jakarta.

Widyaningsih. (2013). Hukum Pajak Dan Perpajakan. Alfabeta. Bandung.

Zuraida Ida. (2014). Teknik Penyusunan Peraturan Daerah Tentang Pajak Daerah Dan Retribusi Daerah. Sinar Grafika. Jakarta. 